\title{
The Effect of Changes in GDP and Interest Rate on Savings: Panel Data Evidence on 6 ASEAN Countries
}

\author{
Nurhikmah Ola Lairi ${ }^{1}$, Cheng-Wen Lee ${ }^{1}$ \\ ${ }^{1}$ Chung Yuan Christian University, Taiwan \\ Correspondence: Nurhikmah Ola Lairi, Chung Yuan Christian University, Taiwan.
}

Received: June 27, 2016

Accepted: July 5, 2016

Online Published: August 31, 2016

doi:10.11114/bms.v2i3.1699

URL: http://dx.doi.org/10.11114/bms.v2i3.1699

\begin{abstract}
The objecive of this study is to examine the relationship between GDP, Interest rate and saving across the ASEAN-6 countries namely Indonesia, Malaysia, Singapore, Vietnam, Philippines and Thailand using Panel Data Econometrics. This paper uses Hausman Test to come up with fixed effect model as the best model. The study found the positive relation between GDP and Interest rate with saving.
\end{abstract}

Keywords: GDP, interest rate, saving, growth rate, ASEAN-6, panel data estimation

\section{Introduction}

GDP is used to measure the economic growth. GDP quantifies the total income of the people. The gross domestic product (GDP) measures of national income and output for a given country's economy. Gross domestic product (GDP) is the market value of all goods and services produced within a country in a given period of time

In the long run growth in gross domestic product, saving and investment are the most important determinants. Sollow predicted that the income between one country another country is different because of the differences in saving and productivity or population growth. Solow in his theory stated that investment and saving, population growth and technology has effect on the output of the economic and economic growth. The model of his theory is $\mathrm{Y}=\mathrm{F}$ (K.L). $\mathrm{Y}=$ output, $\mathrm{K}=$ Physical model, $\mathrm{L}=$ working level. According to Solow, the economic growth depends on the capital development and the population growth. The capital is influenced by the saving and depreciation of capital so that the capital might become zero. This situation occurs because the value of the capital which is formed or depreciation is the same. In the Macroeconomic, this condition makes the economic situation in stable condition with fixed income. Solow stated that the higher level of savings of a State, the richer the country. The higher the population growth rate, the higher the poverty rates. Malthus in his theory also stated that if the population growth is higher it will cause the decrease of the natural resources.

Some literature explained the correlation between saving rate and economic growth with study focus in three aspects. First is to explain the sources of the economic growth and seek the positive effect from saving as an exogenous variable to income and growth. Second, the study aims to see the factors determine the saving rate which contributes to growth. Third, the study aims to seek the causality correlation between saving and growth.

Harrod-Domar model considers saving as a major factor of economic growth. This kind of model depends on the marginal propensity to save and capital- output ratio. Neoclassical economic growth theory or well known as Solow growth model believe that saving is an important factor but in the economic growth, saving rate has no influences in the long run because it is only a temporary. Post-neoclassical theory stated that the increase of saving rate will drive the economic growth rate to the higher level permanently, not only contemporarily. Saving rate in this theory implied that saving rate has a positive effect to investment and capital accumulation.

\section{Literature Review}

Some studies have been done relating to the topics of research anayzing the effect of population and savings to the GDP. Jong-Won Yoon, Jinill Kim, and Jungjin Lee (2014) in IMF working paper investigated the Impact of Demographic Changes on Inflation and the Macroeconomic. The research explains and analyzes the moving of demographic variables and the influence of demographic variables such as economic growth, inflation, savings and investment, and fiscal 
balances. The result of their study is the population growth influences real economic variables on the negative side and insignificance in many instances. The research shows the population growth affects the inflation rate positively.

According to their research, the impact of population aging on economic growth depends on several factors including a country's savings rates, capital stock, access to foreign capital, and initial level of retirees.

Minh Quang Dao (2012) in his study "Population and economic growth in developing countries" analyzes the growth rate of per capita GDP to population growth. The result of the study concludes that there is correlation between the growth rate of per capita GDP and population growth, dependency ratios and mortality rate. The condition applies when the rate of population growth is less or more than 1.2 percent per year.

The effects of mortality decline has been analyzed by Bloom and Canning (2001) and Kalemli-Ozcan (2002). Their studies shows that the mortality decline in developing countries affects the educational attainment and savings rates. When the mortality rate decline, the educational atainment and saving rates becomes high. This stuation influences the increasement of the investment in physical and human capital.

The 2004 World Economic Outlook by Callen et al. (2004) in Chapter 3 shows positive correlation between per capita GDP growths with changes in the working age population share. The research shows negative correlation between per capta GDP growth with changes in the elderly share. In this study, we would attempt to see in the GDP aspect in relating to the population and saving to extend the essential findings of Callen et al. in relating to this study.

Emmanuel Anoruo and Yusuf Ahmad in his study Causal Relationship between Domestic Savings and Economic Growth: Evidence from Seven African Countries (American Development Review 2002) conducted a study to find out whether increases in GDP Granger influences the growth rate of domestic savings or vice versa. The research analyzes the result in long run relationship between economic growth and growth rate of savings. The results from the Granger causality tests indicate that the economic growth prima facie causes growth rate of domestic savings for most of the countries under consideration. This result contrary to the conventional wisdom that the economic growth has no relationship to grwoth rate of domestic savings.

Lee et al (2007) estimate the impact of longevity and population aging on saving, investment, and growth rates independently. Their study find that an increase in population aging reduces saving rates and an increase in the relative size of the working age population increases economic growth rates.

Aghevli et al (1990) in his work, a comprehensive study for 85 developing countries using panel data, found out that net national savings rate with economic growth has a positive relationship, and with inflation rate, liquidity ratio to GDP ratio, urbanization and the foreign debt problem has negative relationship.

Sadi (2006) used Time series data of 1971-2003 to find out the determinants of domestic savings of Iran. The result was all the growth of GDP, current balance, population growth, changes in oil prices and exchange relationship are directly related to savings, and the correlation between savings rates and inflation is negative.

Warren Tease, et al in the OECD Economic Studies Autumn 1991 analyzes the influence of saving investment and other factors examined the behavior of saving, investment and real interest rates over the past few decades. The study also analyzes relating factors such as government saving, developments outside OECD area, and demographic changes. The result of the study find there is lower trend of the global saving and interest rate in 1980s compare to the previous decade. In the early 1980s, OECD countries and certain parts of non OECD regions have decrease in saving and investment rates. In this case, the decrease in national saving refers to decrease in government saving. Private saving has little influences in this matter and the declines in private investment refers to the fall in national investment rates.

Our study differs from the previous study. First, our paper uses three variables of GDP and interest rate examine the relationship with Saving while other studies only use saving and GDP. Second our study focuses on ASEAN countries that are having good growth in GDP. Third, previous study also has little work focus in analyzing the relationship between Saving, GDP, and interest rate in the ASEAN countries.

\subsection{Overview of ASEAN-6 Countries}

The Gross domestic product growth in the ASEAN countries particularly the 6 main ASEAN countries namely Indonesia, Malaysia, Singapore, Vietnam, Philippines, and Thailand have been relatively well and improve. These six countries have strong performance for the year 2013 and 2014 and are expected to remain high. From these countries, Philippines, Indonesia, Malaysia and Thailand are named as the Tiger Club Economies

\subsubsection{Indonesia}

Indonesia is the fourth largest country in terms of population size. Total population of Indonesia in 2014 is 250 million people. Indonesia has grown strongly since 2010. Indonesia was successful to join China and India as the G20 members in growth. Indonesia currently in the end year of 2014 has a new president and run to perform better attempt to improve 
the economic situation and trading policy of Indonesia. Future forecasts for Indonesia's economic development are positive. However Indonesia needs to empower the effort regarding poverty and unemployment, the imrpovement of infrastructure and control of corruption actions. Indonesia also struggle to reduce fuel subsidies from the government.

\subsubsection{Malaysia}

Malaysia's economic freedom score is 69.8. In term of economic freedom, Malaysia has ranked as top 9 from 42 countries in the Asia-Pacific. Malaysia has rank as the 7 position from 10 economic freedoms in terms of financial freedom, investment freedom, labor freedom and business freedom. Malaysian economy is a growing and relatively open state oriented. Malaysia was the $3^{\text {rd }}$ largest economy in South East Asia and $29^{\text {th }}$ largest economy in the world. The GDP in 2009 was US\$ 383.6 billion and the nominal per capita GDP was US\$ 8,100. In 2013 the GDP growth was 4.7 $\%$. The fiscal consolidation is on track and current account to stay in surplus but risks to both oil prices fall further.

\subsubsection{Singapore}

According to the World Bank, Singapore has a score of economic freedom is 89.4. Singapore is the 2nd freest in the 2014 index. The population is 5.4 million and GDP was \$ 326 billion with annual growth is $5 \%$ a year. Singapore has $2 \%$ unemployment percentage and the inflation (CPI) is $4.6 \%$. Singapore is well known as a country with lack of corruption, pro to business open and low tax rate.

Singapore has become the third highest per-capita GDP in the world in terms of purchasing Power parity. The location of Singapore which are located as in the central link of the region makes the country become the central business exchange and information in the region. The government play important role in the link companies business. The government holds majority share in the largest companies. The economy model is Foreign Direct Investment outflow financier in the world. Singapore has a very beneficial from this status and also benefited from inward flow of FDI from investors because of the high trust of the investors to Singapore. Singapore is concern as a save and stable political situation.

\subsubsection{Philippine}

According to World Bank Statistics, Philippine economy is the $39^{\text {th }}$ largest in the world. Philippine is one of the emerging markets and considered as an industry market. According to Goldman Sachs, Philippine will be the $14^{\text {th }}$ largest economy in the world and $5^{\text {th }}$ largest in Asia.

Philippines exports goods are electronic, semiconductors, equipment of transport, garments, coconut oil, copper and petroleum. Philippines include as the fastest economic growing country in Asia. The major problem faced by Philippines are the corruption, still lack of infrastructure and unequal income and growth, social status and economic classes between one region to other region

Philippines has large agricultural sector, industrial sector from foreign multinational corporations, overseas Filipino workers. Filipino workers is one of the big to the economy.

\subsubsection{Vietnam}

The population of Vietnam is 90.4 million and the GDP is $\$ 320.7$ billion. The growth is $5.0 \%$. The score of economic freedom of Vietnam is 50,8 . The economy freest was $147^{\text {th }}$ in the 2014 index. The problems are encountered by Vietnam are corruption, monetary freedom, and business freedom and fiscal freedom. Vietnam is in the rank of 22rd in the Asia Pacific region. Vietnam overall score is lower than the world and regional averages.

\subsubsection{Thailand}

Thailand has a big dependent on export with more than two-thirds of its Gross Domestic Product. The score of freedom is 63.3. Thailand is the 72nd freest in the 2014 Index. Thailand has a low score for business freedom.

The population depends on agriculture employs with $50 \%$. The agricultures products are rice, rubber, corn, sugarcane, coconuts and soybeans. The exports are commodities and farmed scrimp. The population of Thailand is 64.4 million. According to World Bank, Gross domestic saving (\% of GDP) in Thailand was 30.80 in 2014.

\section{Methodology}

\subsection{Data}

Data for this research is a secondary data from World Bank and International finance statistics Publication

\subsection{Variables}

The dependent variable of this study is saving. The independent variables are GDP and Interest Rate. 


\subsection{Model Regression}

This study uses a panel data regression. This study runs the estimation using either fixed or random effect technique. If individual specific component is assumed to be random with respect to the explanatory variables then we use random effect estimator. We apply the fixed effects estimator if the individual specific component is not independent with respect to the explanatory variables. Three approaches to run the data of the panel data in this study: Pooled Model, Fixed Effect Model, and Random Effect Model.

The panel in this study consists of time series and cross section data. The time series variable observations consist of years 1990 until year 2014. For the cross section data, the study uses the country form selected ASEAN countries Indonesia, Malaysia, Singapore, Philippine, Thailand and Vietnam. The data is balanced panel data means that there is no missing observation.

\section{Empirical Results and Interpretation}

The effect of GDP and interest rate on saving: Panel Data Evidence on 6 ASEAN Countries is clearly defined in this study after doing all the tests. The researcher was able to find out that the best model for this study is fixed effect model. The model uses $p$-values to indicate the statistical significance of the values of the parameters.

\section{A. Ordinary least Square ( OLS)}

OLS regression model neglect the cross section and time series nature of data. We deny the heterogeneity and individuality within the countries. We assume all countries are the same but normally they are not same.

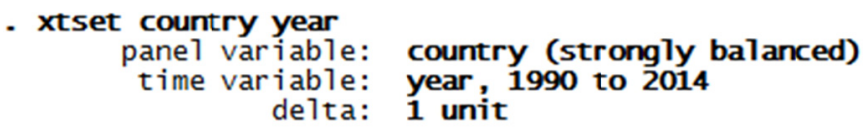

- xtsum saving gdp interest

\begin{tabular}{|c|c|c|c|c|c|c|c|}
\hline variable & & Mean & Std. Dev. & Min & $\operatorname{Max}$ & obse & ions \\
\hline saving & $\begin{array}{l}\text { overal1 } \\
\text { between } \\
\text { within }\end{array}$ & 33.72667 & $\begin{array}{l}9.854578 \\
7.663541 \\
6.916841\end{array}$ & $\begin{array}{r}13 \\
26.16 \\
13.88667\end{array}$ & $\begin{array}{r}60 \\
46.28 \\
55.88667\end{array}$ & $\begin{array}{l}\mathrm{N}= \\
\mathrm{n}= \\
\mathrm{T}=\end{array}$ & $\begin{array}{r}150 \\
6 \\
25\end{array}$ \\
\hline gdp & $\begin{array}{l}\text { overal1 } \\
\text { between } \\
\text { within }\end{array}$ & 1. $70 \mathrm{e}+08$ & $\begin{array}{l}1.60 e+08 \\
1.01 e+08 \\
1.30 e+08\end{array}$ & $\begin{array}{r}6471740 \\
6.16 e+07 \\
-9.10 e+07\end{array}$ & $\begin{array}{l}8.77 e+08 \\
3.56 e+08 \\
6.90 e+08\end{array}$ & $\begin{array}{l}\mathrm{N}= \\
\mathrm{n}= \\
\mathrm{T}=\end{array}$ & $\begin{array}{r}150 \\
6 \\
25\end{array}$ \\
\hline interest & $\begin{array}{l}\text { overall } \\
\text { between } \\
\text { within }\end{array}$ & 4. 979333 & $\begin{array}{l}4.413209 \\
.7448314 \\
4.360161\end{array}$ & $\begin{array}{r}-24.6 \\
3.788 \\
-25.38867\end{array}$ & $\begin{array}{r}17.7 \\
5.768 \\
16.91133\end{array}$ & $\begin{array}{l}\mathrm{N}= \\
\mathrm{n}= \\
\mathrm{T}=\end{array}$ & $\begin{array}{r}150 \\
6 \\
25\end{array}$ \\
\hline
\end{tabular}

- regress saving gdp interest

\begin{tabular}{|c|c|c|c|c|c|}
\hline Source & SS & df & MS & Number of obs $=$ & \\
\hline $\begin{array}{r}\text { Mode1 } \\
\text { Residual }\end{array}$ & $\begin{array}{l}624.797083 \\
13844.9963\end{array}$ & $\begin{array}{r}2 \\
147\end{array}$ & $\begin{array}{r}312.398541 \\
94.183648\end{array}$ & $\begin{array}{l}\text { Prob > F } \\
\text { R-squared }\end{array}$ & $\begin{array}{l}0.0390 \\
0.0432\end{array}$ \\
\hline Total & 14469.7933 & 149 & 97.1127069 & Root MSE & 9.7 \\
\hline
\end{tabular}

\begin{tabular}{r|rcccrr}
\hline saving & coef. & std. Err. & $t$ & $\mathrm{P}>|t|$ & \multicolumn{1}{c}{ [95\% conf. Interval] } \\
\hline gdp & $\mathbf{1 . 5 2 e - 0 9}$ & $\mathbf{4 . 9 9 e - 0 9}$ & $\mathbf{0 . 3 1}$ & $\mathbf{0 . 7 6 1}$ & $\mathbf{- 8 . 3 3 e - 0 9}$ & $\mathbf{1 . 1 4 e - 0 8}$ \\
interest & $-\mathbf{4 5 6 1 1 2 1}$ & $\mathbf{. 1 8 0 7 8 8 2}$ & $-\mathbf{2 . 5 2}$ & $\mathbf{0 . 0 1 3}$ & $-\mathbf{8 1 3 3 9 1 8}$ & $-\mathbf{0 9 8 8 3 2 4}$ \\
_cons & 35.73907 & $\mathbf{1 . 5 1 1 5 8 9}$ & $\mathbf{2 3 . 6 4}$ & $\mathbf{0 . 0 0 0}$ & $\mathbf{3 2 . 7 5 1 8 2}$ & $\mathbf{3 8 . 7 2 6 3 2}$ \\
\hline
\end{tabular}

\section{B. FIXED EFFECT}

The fixed effect model or LSDV model allows for heterogeneity or individuality among countries by allowing to have own intercept value. Intercept may differ across countries but intercept not vary over time. Fixed effect model is time invariant. 


\begin{tabular}{|c|c|c|c|c|c|}
\hline \multicolumn{4}{|c|}{$\begin{array}{l}\text { Fixed-effects (within) regression } \\
\text { Group variable: country }\end{array}$} & $\begin{array}{l}\text { Number of obs } \\
\text { Number of groups }\end{array}$ & \multirow{2}{*}{$\begin{array}{lr}= & 150 \\
= & 6 \\
= & 25 \\
= & 25.0 \\
= & 25\end{array}$} \\
\hline $\begin{array}{ll}\text { R-sq: } & \text { within } \\
\text { between } \\
\text { overall }\end{array}$ & $\begin{array}{l}=0.1188 \\
=0.0679 \\
=0.0155\end{array}$ & & & obs per group: $\begin{aligned} & \min = \\
& \operatorname{avg}= \\
& \max =\end{aligned}$ & \\
\hline $\operatorname{corr}\left(u_{-} i, x b\right)$ & $=-0.1988$ & & & $\begin{array}{l}\mathrm{F}(2,142) \\
\mathrm{Prob}>\mathrm{F}\end{array}$ & $\begin{array}{r}9.57 \\
0.0001\end{array}$ \\
\hline saving & coef. & Std. Err. & $t$ & [95\% conf. & . Interval] \\
\hline $\begin{array}{r}\text { gdp } \\
\text { interest } \\
\text { _cons }\end{array}$ & $\begin{array}{l}1.47 \mathrm{e}-08 \\
-.262319 \\
32.53021\end{array}$ & $\begin{array}{l}4.23 e-09 \\
.1265591 \\
1.163403\end{array}$ & $\begin{array}{r}3.48 \\
-2.07 \\
27.96\end{array}$ & $\begin{array}{r}6.35 \mathrm{e}-09 \\
-.5125025 \\
30.23038\end{array}$ & $\begin{array}{r}2.31 \mathrm{e}-08 \\
-.0121355 \\
34.83004\end{array}$ \\
\hline $\begin{array}{r}\text { sigma_u } \\
\text { sigma_e } \\
\text { rho }\end{array}$ & $\begin{array}{l}8.1444085 \\
6.6512306 \\
.59990264\end{array}$ & (fraction & f varia & ce due to $u_{-} i$ ) & \\
\hline
\end{tabular}

Then the study aim to seek LSDV:

Individual Effect by each country by LSDV (Least square Dummy Variable)

- estimates store fixed

- tabulate country,gen( country)

\begin{tabular}{r|rrr} 
country & Freq. & Percent & cum. \\
\hline 1 & 25 & $\mathbf{1 6 . 6 7}$ & $\mathbf{1 6 . 6 7}$ \\
2 & 25 & $\mathbf{1 6 . 6 7}$ & 33.33 \\
3 & 25 & $\mathbf{1 6 . 6 7}$ & 50.00 \\
4 & 25 & $\mathbf{1 6 . 6 7}$ & $\mathbf{6 6 . 6 7}$ \\
5 & 25 & $\mathbf{1 6 . 6 7}$ & $\mathbf{8 3 . 3 3}$ \\
6 & 25 & $\mathbf{1 6 . 6 7}$ & $\mathbf{1 0 0 . 0 0}$ \\
\hline Tota1 & $\mathbf{1 5 0}$ & $\mathbf{1 0 0 . 0 0}$ &
\end{tabular}

- regress saving gdp interest country1- country6, nocons

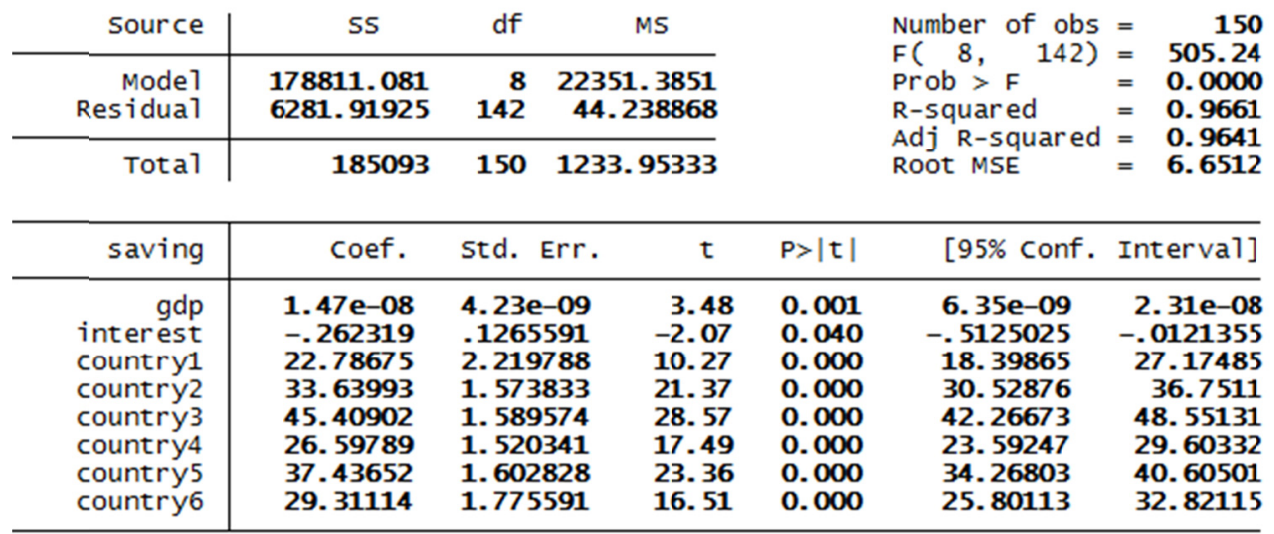

Random Effect Model

In random effect model allows among countries have a common mean value for the intercept 


\begin{tabular}{|c|c|c|c|c|c|}
\hline \multicolumn{4}{|c|}{$\begin{array}{l}\text { Random-effects GLS regression } \\
\text { Group variable: country }\end{array}$} & $\begin{array}{l}\text { Number of obs } \\
\text { Number of groups }\end{array}$ & $\begin{array}{r}150 \\
6\end{array}$ \\
\hline 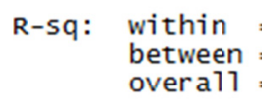 & \multicolumn{3}{|l|}{$\begin{array}{l}=0.1187 \\
=0.0658 \\
=0.0165\end{array}$} & obs per group: $\begin{aligned} & \min = \\
& a v g= \\
& \max =\end{aligned}$ & $\begin{array}{r}25 \\
25.0 \\
25\end{array}$ \\
\hline $\begin{array}{l}\text { Random effects } \\
\operatorname{corr}\left(u_{-} i, x\right)\end{array}$ & \multicolumn{3}{|c|}{$\begin{aligned} u_{-} i & \sim \text { Gaussian } \\
& =\mathbf{0} \text { (assumed) }\end{aligned}$} & $\begin{array}{l}\text { Wald chi2(2) } \\
\text { Prob }>\text { chi2 }\end{array}$ & $\begin{array}{r}18.60 \\
0.0001\end{array}$ \\
\hline saving & coef. & Std. Err. & $z$ & {$[95 \%$ conf. } & =. Interval] \\
\hline $\begin{array}{r}\text { gdp } \\
\text { interest } \\
\text { _cons }\end{array}$ & $\begin{array}{r}1.42 \mathrm{e}-08 \\
-.2689537 \\
\mathbf{3 2 . 6 5 3 9 1}\end{array}$ & $\begin{array}{l}4.20 \mathrm{e}-09 \\
.1264309 \\
3.499729\end{array}$ & $\begin{array}{r}3.38 \\
-2.13 \\
9.33\end{array}$ & $\begin{array}{r}5.95 e-09 \\
-.5167536 \\
25.79457\end{array}$ & $\begin{array}{r}2.24 \mathrm{e}-08 \\
-.0211537 \\
39.51325\end{array}$ \\
\hline $\begin{array}{r}\text { sigma_u } \\
\text { sigma_e } \\
\text { rho }\end{array}$ & $\begin{array}{l}8.0917994 \\
6.6512306 \\
.59678777\end{array}$ & (fraction & f varia & ce due to $u_{-} i$ ) & \\
\hline
\end{tabular}

\section{Hausman Test}

Hausman test is used to check which model is suitable for the study.

Null Hypothesis: Random- effect is appropriate

Alternative hypothesis: Fixed-effect model is appropriate

If statistically significant P-Value, the study will use fixed effect model, rather than Random Effect model.

$$
\begin{aligned}
& \text { - hausman fixed } \\
& \text { Note: the rank of the differenced variance matrix (1) does not equal the number of coefficients bt }
\end{aligned}
$$

\begin{tabular}{|c|c|c|c|c|}
\hline & \multicolumn{2}{|c|}{$\longrightarrow$ Coefficients $\longrightarrow$} & \multirow[b]{2}{*}{$\begin{array}{c}(b-B) \\
\text { Difference }\end{array}$} & \multirow[b]{2}{*}{$\begin{array}{c}\operatorname{sqrt}\left(\operatorname{diag}\left(V_{-} b-\mathrm{b}-V_{-} \mathrm{B}\right)\right) \\
\text { S.E. }\end{array}$} \\
\hline & $\begin{array}{l}\text { (b) } \\
\text { fixed }\end{array}$ & (B) & & \\
\hline $\begin{array}{r}\text { gdp } \\
\text { interest }\end{array}$ & $\begin{array}{l}1.47 e-08 \\
-.262319\end{array}$ & $\begin{array}{r}1.42 \mathrm{e}-08 \\
-.2689537\end{array}$ & $\begin{array}{l}5.33 e-10 \\
.0066347\end{array}$ & $\begin{array}{l}5.10 \mathrm{e}-10 \\
.0056961\end{array}$ \\
\hline
\end{tabular}

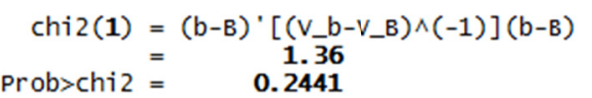
expect, or there may be problems computing the test. Examine the output of your estimator

\section{Conclusion and Recommendation}

The study is analyzed by panel data method. The study find out that fixed effect model is the best model. The study rejects the null hypothesis and accept alternative hypothesis. Our first assumption related to the literature, we assumed that the a priori expectation of the model is random effects model. We used the fixed effect model because the value of rho is close to $1(.5697)$.

The result showed the positive correlation between saving and GDP. The GDP is very significant $(0.001)$ related to saving with coefficient 1.47. Interest Rate is significant related to saving but the coefficient is negative (-.262319).

\section{References}

Aghevli, B. B., Boughton, J. M., Motiol, P. J., Villanueva, D., \& Woglom, G. (1990). The Role of National Saving in the World Economy: Recent Trends and Prospects. IMF, (67), 39-45.

Emmanuel, A., \& Yusuf, A. (2001). Causal Relationship between Domestic Savings and Economic Growth: Evidence from Seven African Countries. African Development Bank. Blackwell publishers, Oxford, UK.

Jong-Won, Y., Jinill, K., \& Lee, J. J. (2014). Impact of Demographic Changes on Inflation and the macroeconomy. IMF working paper.IMF WP/14/210.

Lee, S. H., \& Mason, A. (2007). Who Gains from the Demographic Dividend? Forecasting Income by Age, 
International Journal Forecast, 23, 603-619. http://dx.doi.org/10.1016/j.ijforecast.2007.07.004

Minh, Q. D. (2012). Population and Economic Growth in Developing Countries. International Journal of Academic Research in Business and Social Sciences, 1(2).

Ritesh, K. S. (2008). Impact on Savings Due to Changes in GDP and Rate of Interest in India. International Conference on Applied Economics-ICOAE 2008855

Sadi, M. (2006). Effects of Macroeconomic Policies in Mobilizing Domestic resources for investment in Iran. Economic Research, (19), 235-262.

Warren, T. Andrew, D., Jorgen, E., \& Peter, H. (1991). Real Interest Rate Trends: The Influence of Saving. Investment and Other Factors. OECD Economic Studies No. 17. Autumn 1991.

\section{$(\mathrm{Cc}) \mathrm{EY}$}

This work is licensed under a Creative Commons Attribution 3.0 License. 